\title{
Model of Poor Fishermen Empowerment in Kelurahan Pasia Nan Tigo Padang West Sumatra
}

\author{
Syahrizal $^{1}$, Rinaldi Eka Putra ${ }^{2}$, and Yevita Nurti ${ }^{3}$ \\ \{syrizal81@gmail.com\} \\ Lecturer at Anthropology Department Social and Political Science Fakulty Andalas Universty Padang \\ West Sumatra, Indonesia ${ }^{1,2,3}$
}

\begin{abstract}
This article is based on research on fishermen in Pasia Nan Tigo urban village Padang West Sumatra. Most of fishermen in Pasia Nan Tig are small-scale and they live in poverty. So far, there are many empowerment programs which conducted by both government and non-governmental organizations to improve the welfare of fishermen. But these programs have not succeeded in improving the welfare of fishermen that live in poverty. This study tries to see the causes of difficulty in improving the living standards of fishermen despite many empowerment programs undertaken and potentials owned by fishermen. The study was conducted in an urban village using qualitative research methods to do fieldwork by doing with observasi and in-depth interviews. The results of research show that empowerment programs often did not see what is needed by the fishermen and also the gift is also not on target. Poor fishermen did not had a bargaining position they just accept what the government or elite programs do in their homes. To improve the welfare of fishermen it is important to see the potential of the fishermen and see their aspirations. The potential of the fishermen is that they are urban fishermen, where the city has adequate facilities and infrastructure for fishermen's progress. Education children who can be better than parents and the wives who can develop their own business to increase family income..
\end{abstract}

Keywords: fishermen, poverty, empowerment, potential, aspirations.

\section{Introduction}

The wealth of Indonesia's natural resources in the form of vast oceans and fish in them is not yet able to prosper fishermen because most of the fishermen in Indonesia are still living in conditions of poverty. The average income of low fishermen is only enough to meet the daily subsistence needs of families. Fishermen's income with traditional fishing equipment is very fluctuating because it is influenced by weather, season, and fate factors. The government has tried to empower fishermen who aim to improve their welfare. The empowerment is by carrying out various programs, but the empowerment programs of the fishing community from the government do not or have not been able to improve the standard of living of small-scale fishermen or traditional fishermen and fishermen of the ship's crew or labor fishermen.

This raises the question of why programs to eradicate fishermen from poverty do not produce what is expected. Does this relate to poverty alleviation programs which so far have only been top down not buttom based on aspirations or needs and desires of fishermen. What is the perspective of the fishermen themselves is actually about poverty alleviation programs that have been carried out by the government. What empowerment models are suitable to 
improve the living standards of poor fishermen. This article is based on the results of research aimed at: 1) Explaining poor fishermen's perceptions of empowerment programs that have been carried out by the government; 2) Identify the causes of failure of poor fishermen community empowerment programs; and 3) Identify potentials that can be developed for empowerment based on available resources and aspirations of poor fishing communities.

\section{Methodology}

To capture the perceptions and aspirations of the poor fishing community, the research uses ethnographic research techniques. Ethnography is considered as a form of research that focuses on social meaning through observation of socio-cultural phenomena (Clifford, 1999). Then inspired by grounded theory (Glasser and Strauss, 1967) In this case it focuses on how fishing communities living in poverty interpret their lives, define their problems and produce meaning that allows them to see themselves as individuals in a wider society. This makes it possible to explain how people act based on their perceptions, such as how they respond by trying to improve their conditions, relationships, and capacities.

\section{Research findings}

The problem of poverty in fishing communities is actually a complex problem. As previously explained based on the results of studies conducted by researchers there are several factors that cause fishermen's poverty, including: (1) government policies in the field of fisheries that are more concerned with capital owners than improving the standard of living of fishermen, (2) scarcity resources due to over production or theft of fish by foreign fishermen; (3) inequality in the production sharing process among fishermen owners with labor fishermen there is a kind of exploitation of labor fishermen; (4) fishing equipment or equipment that is still simple; (5) fish prices fluctuate; and (6) and weather conditions that make fishermen unable to go to sea; (7) the residence of the fishing community isolated from transportation and communication facilities.

Residents in Pasie Nan Tigo Village have livelihoods, among others, as fishermen, civil servants, the private sector, and others. Most of the work of the Pasie Nan Tigo community is Fishermen. even more than half of the residents of Pasie Nan Tigo village have their main livelihood as fishermen. This is supported by the Tigo Nan Pasie region on the coast of West Sumatra. So that it can be said that the superior and main economy of the community is from fisheries, especially marine fisheries.

The role of the government in overcoming the problem of poverty to the community is to provide assistance programs either in the form of direct assistance or sustainable assistance such as skills training. Fishermen are one of the elements of the community that received a lot of attention by the government regarding the empowerment program for the welfare of their lives, including fishermen in Pasie Nan Tigo Village. Especially traditional fishermen who use long tail fishing gear, quite a lot get a portion of this empowerment program. Because the number of long tail machine fishermen or more often known as biduak fingerang is very large, the distribution of aid is often given through groups that they form themselves based on direction and guidance from the Marine and Fisheries Service (DKP).

Various forms of responses and perceptions that grew among fishermen who were touched by the way of the empowerment programs. There are differences in perceptions 
between individual recipients of assistance with KUB administrators and related agencies, especially assistants or extension workers who are directly involved in coaching and mentoring these fishermen groups. Especially among small fishermen such as fishermen, biduak jariang, clearly explained their views on the practice of empowerment programs in the field.

Some programs and assistance provided positive responses and some also gave a negative impression of the program. Most fishermen's perceptions are often tilted mainly towards the running of the PUMP program which is mostly carried out by KUB based on advice and direction from the ministry of marine affairs and the Padang city fisheries. From the "skewed" perceptions of empowerment programs, finally many cause many inequalities and deviations that occur to the practice of the programs.

About the skills and potential of fishermen, especially traditional fishermen or poor fishermen and their families is a classic thing to discuss. As is well known in general, the developing dogma about fishermen has always been synonymous with the lack and lack of skills and selfpotential that can be developed from these individual fishermen. But if we examine it from within there are some points that can be developed from the fisherman. Although in fact it is still related to the fisheries sector. From the results of this research interview, it was proven that most of the fishermen did not have any other skills at all, especially for those who were 40 years and over.

Meanwhile, if seen by the fishermen's family they have the potential to help the family economy. Fishermen's children generally have higher education than their parents. They can help their parents' economy by working in other sectors. While fishermen's wives can work entrepreneurship by selling. The crowded urban population in the Pasia Nan Tigo area is a potential for the businesses of the fishermen's wives.

\section{CONCLUSION}

This article is based on the results of research on poor fishermen in Pasia Nan Tigo Village, Padang City, West Sumatra. Fishermen here even though living in urban areas with sufficient facilities and infrastructure still live in poverty. Empowerment programs carried out by the government to improve their standard of living have not succeeded in improving their welfare. The problem raised is how the empowerment model is carried out and how the fishermen's perception of the program is carried out.

There are many empowerment programs carried out by the government but the program does not pay attention to the actual conditions and needs of the fishing community. The direct assistance program in the form of giving ships does not pay attention to the traditions and skills of the community. The group assistance program has problems with wrong targets, irregularities, and perceptions of the fishermen themselves about assistance. The fishermen empowerment model must pay attention to the real conditions of the fishing community, paying attention to the values, the structure of the community, and the potential they have. In order for empowerment to be carried out, it can touch the needs of the fishermen themselves. . 


\section{References}

[1] Acheson James M. (1981). “Anthropology of Fishing,” Annual Anthropology, 10, 275-316.

[2] (2006). "Institusional Failure in Resource Management," Annual Review,35,117-134

[3] Alexander, Paul (1982). Sri Lankan Fishermen: Rural Capitalism and Peasant Society. Canberra: Australian University.

[4] Bene, Christhophe (2003). "When Fishery Rhymes with Poverty: A First Step Beyond the Old Paradigm on Poverty in Small-Scale Fisheries," World Development, 31, 949975.

[5] Bernstein, Henry \& Others Ed. 1992, Poverty and Development in the 1990s, Oxford: Oxford University Press.

[6] Betke, Fried Helm (1985).Modernization and Socio Economic Change in the Coastal Marine Fisheries of Java Some Hypothesies. Bieleveld: University of Bieleveld.

[7] Collier William (1980).“'Observation Two Sea Fishing Villages in Sumatera and Kalimantan,'Indonesia Circle, 22, 33-54.

[8] Dinas Perikanan dan Kelautan Sumbar (2010). Statistik Perikanan Tangkap Sumatera Barat. Padang: DPK

[9] Dove, Michael R. (Ed.) (1985). Peranan Kebudayaan Tradisional Indonesia dalam Modernisasi, Jakarta: Yayasan Obor Indonesia.

[10] Elfindri (2002). Ekonomi Patron Klien: Fenomena Mikro Rumah Tangga Nelayan dan Kebijakan Makro. Padang: Andalas University Press.

[11] Gans, Herbert J.(1969). The Urban Villagers: Group and class in the life of Italian Americans. New York: The Free Press.

[12] _ (1993) "Kebudayaan Kelas dalam Studi Mengenai Kemiskinan: Sebuah Pendekatan Terhadap Penelitian Anti Kemiskinan" dalam Parsudi Suparlan (Ed.). Kemiskinan di Perkotaan, Jakarta:Yayasan Obor Indonesia.

[13] Goodwin, Larry Allan (1983). Change is Continuity: The maritime and Subsistence Economics of Ponape Micronesia. Disertasi Graduate School of the University of Oregon.

[14] Hashim, Wan (1995). Peasants under Peripheral Capitalism. Bangi: University Kebangsaan Malaysia.

[15] Imron, Masyhuri dan M.Azzam Manan (2009), Strategi Nelayan dalam Meningkatkan Kesejahteraan: Alternatif, Kendala, dan Dukungan Kebijakan. Jakarta: Lembaga Ilmu Pengetahuan Indonesia.

[16] Juliantono, Ferry Joko (2015). Dinamika Relasi Agen dan Struktur Dalam Reproduksi Kemiskinan Masyarakat Nelayan: Studi Atas Masyarakat Nelayan di Desa Teluk Labuan Banten. Jakarta: Disertasi UI

[17] Kettering, Sharon (1986). Patrons, Broker, and Cilents in Seventeenth-Century France. Oxford: Oxford University Press.

[18] Kleden, Ninuk dan M.Ali Humaidi (2010). Segoro dan Negoro: Kemiskinan dari Perspektif Kebudayaan. Jakarta: Lembaga Ilmu Pengetahuan Indonesia.

[19] Kusnadi (2002). Konflik Sosial Nelayan:Kemiskinan dan Perebutan Sumberdaya Perikanan. Yogyakarta: LKis.

[20] Marahudin Firial dan Ian R.Smith (1987). Ekonomi Perikanan: Dari Pengelolaan ke Permasalahan Praktis. Jakarta: Gramedia.

[21] Marbun, Leonard (2008). Kenaikan BBM dan Kemiskinan Nelayan. Medan: P3MN.

[22] Masyhuri (2001). Dimensi Ekonomi Kehidupan Sosial Masyarakat Nelayan, Jurnal Ekonomi dan Pembangunan,9, 73-98. 
[23] Pittaluga, Fabio (2007). Poverty, Fishing and Livelihoods on Lake Kossou, Cote D'ivoire. Disertasi The University of Arizona.

[24] Said, Kamaruddin M. (1993). The Despairing and The Hopefull A Malay Fishing Community in Kuala Kedah. Kuala Lumpur: University Kebangsaan Malaysia.

[25] Salagrama, Venkatesh (2006). Trends in Poverty and Livelihoods in Coastal Fishing Communities of Orissa State, India. Rome: Food and Agriculture Organizations.

[26] Satria, Arif (2002).Pengantar Sosiologi Masyarakat Pesisir. Jakarta: Cidesindo.

[27] _ (2009).Ekologi Politik Nelayan. Yogyakarta: LKis.

[28] Siswanto, Budi(2008).Kemiskinan dan Perlawanan Kaum Nelayan. Malang: Mediatama.

[29] Stack, B Carol (1975). All Our Kin: Strategies For Survival in Black Community. London: Harper \& Row.

[30] Suparlan, Parsudi (1993).Kemiskinan di Perkotaan, Jakarta: Yayasan Obor Indonesia.

[31] Usman, Sunyoto (1993). Perspektif Kultural dan Struktural Kemiskinan, Paper. Yogyakarta: Universitas Gajah Mada.

[32] Willigen, John van (2000). Applied Anthropology: An Introduction, Massachusetts: Bergin \& Garvey Publisher, Inc. 